\section{Plant Growth and Physiological Responses to Improved Irrigation and Fertilization Management for Young Peach Trees in the Southeastern United States}

\author{
Bruno Casamali \\ Department of Horticulture, University of Georgia, 1109 Experiment Street, \\ Griffin, GA 30223
}

\author{
Marc W. van Iersel \\ Department of Horticulture, University of Georgia, 1111 Plant Sciences \\ Building, Athens, GA 30602
}

\author{
Dario J. Chavez \\ Department of Horticulture, University of Georgia, 1109 Experiment Street, \\ Griffin, GA 30223
} Additional index words. drought, fruit yield, photosynthetic assimilation, Prunus persica, tree
growth, water potential

\begin{abstract}
New peach orchards in the southeastern United States are often not irrigated until 3 or 4 years after planting. During those years, the only water comes from rainfall. Droughts in the region are becoming more common, making irrigation more important. At the same time, fertilization practices follow recommendations developed decades ago and may not be optimal for current production practices. This research aimed to investigate the effect of different irrigation and fertilization practices on young 'Julyprince' trees grafted onto 'Guardian ${ }^{\mathrm{TM}}$ ' rootstock. The treatments consisted of irrigated vs. nonirrigated trees, drip- vs. microsprinkler-irrigated trees, and four different fertilizer levels $(25 \%, 50 \%, 100 \%$, and $200 \%$; with $100 \%=$ current fertilizer recommendations). Responses to the treatments varied by year. In 2016, below-average rainfall (severe drought as classified by the U.S. Drought Monitor) was recorded throughout the year. This severe drought reduced the growth of nonirrigated trees compared with irrigated trees (average reductions of $56 \%$ in canopy volume, $39 \%$ in trunk cross-sectional area, $39 \%$ in leaf and stem water potential, and $40 \%$ in leaf photosynthesis). The adverse effects on tree growth and physiological responses of the 2016 season carried over to 2017 , which was characterized by a short period of belowaverage rainfall in early spring. Nonirrigated trees displayed advanced budbreak progression; reduced commercial yield (10.9 vs. $13.4 \mathrm{~kg} /$ tree for nonirrigated vs. irrigated trees); and smaller trunk cross-sectional area (54.0 vs. $\left.70.1 \mathrm{~cm}^{2}\right)$ and canopy volume (8.9 vs. $\left.10.9 \mathrm{~m}^{3}\right)$ compared with irrigated trees. In 2018 , rainfall was like the historical average throughout the year. Major differences continued to be trunk crosssectional area $\left(103.4\right.$ vs. $\left.126.7 \mathrm{~cm}^{2}\right)$ and canopy volume $\left(15.8 \mathrm{vs} .17 .8 \mathrm{~m}^{3}\right)$, with nonirrigated trees being smaller than irrigated trees. No major or consistent differences were found between drip vs. microsprinkler irrigation or among fertilizer levels during the 3 years of the experiment. During the first years of orchard establishments, irrigation resulted in increased plant growth, commercial yield, and superior water status (higher values of water potential) compared with no irrigation, especially when rainfall was below the historical average. Although no major differences were found between the irrigation systems, drip irrigation used $35 \%$ less water than microsprinkler irrigation. While different fertilizer levels did not induce major differences in young trees' growth and yield, potential economic savings and long-term effects of reduced fertilizer applications are being monitored as trees mature.
\end{abstract}

Peach [Prunus persica (L.) Batsch] is a climacteric drupe grown in temperate regions of the world. Georgia is the third largest state producer in the United States with $\approx 4200$ ha of peaches (U.S. Department of Agriculture, National Agricultural Statistics Service, 2017). Peaches have a great significance for the state of Georgia (Okie, 2016), where production and fertilization management (Zhang et al., 2015) in agricultural crops have become priority research areas. Current problems with drought and fertilizer runoff are affecting several regions of the world, including the state of Georgia. Changes in the environment, weather patterns (Rosenzweig et al., 2014), and weather fluctuations (Ray et al., 2015) will soon bring new challenges for agriculture in the southeast region of the United States. Optimal production practices (i.e., irrigation and fertilization) may help trees bear more fruit and bear sooner, thus increasing profitability.

Peaches evolved in Asia in humid and subtropical conditions (Proebsting and Middleton, 1980). The chances are that peaches naturally have high water requirements and are sensitive to water stress (Berman and DeJong, 1996). However, peaches do not tolerate waterlogging (Iacona et al., 2013). Appropriate and precise irrigation management is required for optimal growth and tree health. Most of the peach irrigation studies have been performed in regions with a Mediterranean-type climate (e.g., Spain and California). This is because those regions have experienced droughts (California Department of Water Resources, 2015; Hoerling et al., 2012) more often and longer than the southeastern United States. In those regions, irrigation is essential for crop productivity.

In the southeastern United States, young peach trees typically are not irrigated until 3 or 4 years after planting. Thus, rain is the sole water source until this stage. Dry spring and summer seasons are becoming more common in the southeastern United States (U.S. Department of Agriculture, Forest Service, 2018). Growers need information about optimal irrigation management for young trees, which is currently not available.

In the southeastern United States, Williamson and Coston (1990) evaluated the effect of two irrigation levels on fruit yield and size of 2.5-year-old 'Redhaven' peach trees. They reported no differences in fruit yield and size, and also on most of the vegetative growth parameters evaluated. In contrast, Layne et al. (2002) investigated the combination of three irrigation/fertilization treatments on 1-year-old 'Redglobe' peach trees. They reported that trunk cross-sectional area and fruit yield were greater in treatments with supplemental irrigation, whereas the rainfall-only treatment reduced both fruit yield and marketable fruit.

In California, Goldhamer et al. (2002) imposed regulated deficit irrigation (RDI) or partial root zone drying on 3-year-old 'September Snow' peach trees, finding no differences between treatments for fruit yield, fruit load, and fruit growth rate. The control treatment [crop evapotranspiration (ETc) $+10 \%$ ] yielded heavier fruits, with larger diameter at stage 3 of development (cell expansion stage; Connors, 1919). Control trees had trunk diameter and stem water potential greater than the RDI treatments. Similar effects on fruit yield and weight 
were found by Marsal et al. (2016) in Spain.

In Spain, Girona et al. (2005) reported that RDI during stage 2 of fruit growth development (pit hardening stage; Connors, 1919) resulted in the highest fruit yield and smallest fruit size. RDI during stage 2 of fruit growth development did not affect return bloom and fruit set, while postharvest RDI did. Lopez et al. (2011) discovered that nonirrigated trees yielded smaller fruit, maturing later in the season and with higher dry matter concentration when compared with the full irrigation treatment. In France, Mercier et al. (2009) found that net photosynthesis, stem water potential, stomatal conductance, and transpiration rates were lower for peach trees under severe drought as compared with wellwatered or light water-restriction treatments.

Current fertilizer recommendations for peach tree orchards in the southeastern United States are variable (Ferree and Krewer, 1996; Taylor, 2012), and it is not clear how they were developed. We believe the recommendations are based on studies from the mid-1900s and/or studies performed under environmental conditions not representative of the southeastern U.S. environment. This leaves room for potential improvements and optimization, tailoring guidelines to modern production practices. A reduction in fertilizer use, and early and/or increased fruit production (in year two or three after field planting) may generate additional profits for peach growers.

Fertilization is a basic practice for many crops, affecting the tree's physiology in different ways depending on the form (Lobit et al., 2001) and amount of the nutrient applied (Jordan et al., 2014), as well as the timing of the applications (Niederholzer et al., 2001). Several factors can affect the plants' nutritional levels, such as rainfall, fruit load, pruning, rootstock, nutritional interactions, pesticide applications (Heckman, 2001), and soil physicochemical characteristics (Baligar et al., 2001). In an extensive survey in Pennsylvania, Smith and Taylor (1952) indicated that leaf nitrogen $(\mathrm{N})$ concentrations around $3.5 \%$ represents the optimal value for peaches. Later, in an effort to develop more accurate recommendations in Florida, Gammon and Shoemaker (1963)

Received for publication 7 Oct. 2020. Accepted for publication 22 Dec. 2020.

Published online 29 January 2021.

This material is based on work supported by the Georgia Agricultural Commodity Commission for Peaches, the Georgia Peach Council, Hatch Project GEO00766, and the University of Georgia.

We would like to thank Jerry Davis for help with the statistical design and analysis of the experiment; and Anish Malladi, Wesley Porter, and Juan Carlos Melgar for the valuable research insights and critical reviews of this article in the draft stage. D.J.C. is the corresponding author. E-mail: dchavez@ uga.edu.

This is an open access article distributed under the $\mathrm{CC}$ BY-NC-ND license (https://creativecommons.org/ licenses/by-nc-nd/4.0/). suggested that leaf $\mathrm{N}$ concentration around $3.0 \%$ in late May or early June was optimal. This concentration was reached by applying 44 and $78 \mathrm{~kg} \cdot \mathrm{ha}^{-1} \mathrm{~N}$ in the form of $\mathrm{NH}_{4} \mathrm{NO}_{3}$ for 2- and 3-year-old trees, respectively. They also reported that lower levels of $\mathrm{N}$ reduced yields, and high levels of $\mathrm{N}$ did not have negative effects on fruit color and maturity. In contrast, Crisosto et al. (1997) reported that high levels of $\mathrm{N}$ resulted in poor red fruit color and delayed ripening in 'Fantasia' nectarine in California. In Turkey, Başar (2006) reported that the leaf $\mathrm{N}$ concentration of three peach cultivars, Redhaven, Glohaven, and J. H. Hale, ranged from $2.48 \%$ to $2.85 \%$, and Basar stated that these concentrations were deficient, which agrees with the Gammon and Shoemaker (1963) findings. In research designed to find the best level of $\mathrm{N}$ fertilization for peaches in Florida (planting density of 272 trees/ha), Vashisth et al. (2017) reported that the treatment receiving $90 \mathrm{~kg} \cdot \mathrm{ha}^{-1} \mathrm{~N}$ had the greatest yield, followed by the 0 and $269 \mathrm{~kg} \cdot \mathrm{ha}^{-1} \mathrm{~N}$ treatments. Similarly, Ferreira et al. (2018) tested four fertilizer levels $(0,30,60$, and 120 $\left.\mathrm{kg} \cdot \mathrm{ha}^{-1} \mathrm{~N}\right)$ in a high-density orchard (1333 trees/ha) of young peach trees in Brazil. For 1 - and 2-year-old trees, they found that fertilization above the recommended level for 2 year-old trees $\left(60 \mathrm{~kg} \cdot \mathrm{ha}^{-1} \mathrm{~N}\right)$ did not increase trunk diameter, tree height, and fruit yield. However, for 3-year-old trees, the highest fertilizer treatment increased those variables.

Accurate irrigation and fertilization recommendations for young peach production in the southeastern United States are needed and may create opportunities to increase production efficiency and improve the sustainability of the production system. We hypothesized that 1) irrigated young trees would have a better growth and development and would have greater fruit yield than nonirrigated trees; and 2) that the current fertilizer recommendations for the southeastern United States are not well suited for modern peach orchards. The specific objective of the research was to investigate the physiological and growth responses (leaf and stem water potential, photosynthetic assimilation, water use efficiency, budbreak progression, trunk cross-sectional area, canopy volume, and fruit yield) of young peach trees grown under different irrigation and fertilization regimes.

\section{Material and Methods}

Plant material and field characteristics. 'Julyprince' peach scion grafted onto 'Guardian $^{\mathrm{TM}}$, rootstock in Summer 2014 were planted on 13 July 2015 (358 trees/ha at a spacing of $4.6 \mathrm{~m}$ within rows and $6.1 \mathrm{~m}$ between rows) at the Dempsey Farm, University of Georgia, Griffin, GA (lat.

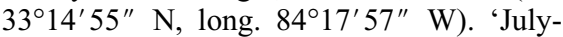
prince' has attractive, large, very firm fruit, and it is a productive and slightly-late variety (Okie and Layne, 2008), ripening in early July in Georgia. 'Guardian ${ }^{\mathrm{TM}}$ ' is a vigorous rootstock (Reighard et al., 1997) tolerant to peach tree short life and resistant to several root-knot nematodes (Nyczepir and Beckman, 2000). Both 'Julyprince' and 'Guard$\operatorname{ian}^{\mathrm{TM}}$ ' are widely used in Georgia. The soil was a Cecil sandy loam, slope of $2 \%$ to $6 \%$, $\mathrm{pH} \approx 5.9$, and organic matter $\approx 1.5 \%$. Baseline soil amendments for $\mathrm{K}, \mathrm{P}$, and lime (to reach $\mathrm{pH}$ 6.0) were made based on soil samples taken before planting, as recommended by the Southeastern Peach, Nectarine, and Plum Pest Management and Culture Guide (Horton et al., 2015). Similarly, pest management practices followed the same culture guide. Monthly average minimum and maximum temperatures and vapor pressure deficit at the Dempsey Farm, Griffin, GA, are shown in Table 1.

Experimental design and treatments. The experiment was designed with three effects: 1) Irrigation levels (irrigated vs. nonirrigated trees); 2) irrigation systems (drip- vs. microsprinkler-irrigated trees); and 3) fertilizer levels $(25 \%, 50 \%, 100 \%$, and $200 \%)$. Hereafter, these three main effect terms will be used throughout the article.

After consulting a research statistician with experience in agricultural research, the experimental field area was divided in two areas, arranging the experiment as a split-plot randomized complete block design. One area had the treatment combinations of 1) dripirrigated vs. nonirrigated trees, with 2) four fertilizer levels each $(25 \%, 50 \%, 100 \%$, and $200 \%$ ), totaling eight combinations. These combinations were randomized and replicated in four blocks. The other area had the treatment combinations of 1) microsprinklerirrigated vs. nonirrigated trees, with 2) four fertilizer levels $(25 \%, 50 \%, 100 \%$, and $200 \%$ ), totaling eight combinations as well. These combinations were also randomized and replicated in four blocks (Fig. 1). Each area was 0.27 ha.

Drip-irrigated trees had four emitters (SB20 Bowsmith; Exeter, CA) placed in a circle at $\approx 45 \mathrm{~cm}$ around the trunk, with each emitter delivering $7.6 \mathrm{~L} \cdot \mathrm{h}^{-1}$, for a total capacity of $30.4 \mathrm{~L} \cdot \mathrm{h}^{-1}$ per tree. Microsprinkler-irrigated trees had one microsprinkler $(\mathrm{QN}-08$ Rain Bird; Azusa, CA) located at $\approx 10 \mathrm{~cm}$ away from the trunk, with a delivering capacity of $30.4 \mathrm{~L} \cdot \mathrm{h}^{-1}$ per tree. In 2016 , the microsprinkler head was set to deliver the water in a $\approx 1.7-\mathrm{m}$ diameter circle around the trunk because the trees were young and small. In May 2017, the microsprinkler head was inverted so the water jets reached a circle of $\approx 3.5 \mathrm{~m}$ diameter around the trunk because of the trees' larger size. This same configuration was used until the end of the experiment.

The irrigation control was done individually for each fertilizer level within each irrigation system (drip or microsprinkler). Two trees of each fertilizer level/irrigation system combination were selected; and for each tree, two soil moisture sensors (10HS; Meter Group; Pullman, WA) were installed, one at $20 \mathrm{~cm}$ and another at $40 \mathrm{~cm}$ depth at $\approx 30 \mathrm{~cm}$ from the trunk. Sensors were connected to nR5-DC nodes (Meter Group) and a Sensorweb base station. The base station collected the volumetric water content 
Table 1. Monthly average minimum and maximum temperatures $\left({ }^{\circ} \mathrm{C}\right)$ and vapor pressure deficit $(\mathrm{kPa})$ from January to December in 2016,2017 , and 2018 at the Dempsey Farm, Griffin, GA.

\begin{tabular}{|c|c|c|c|c|c|c|c|c|c|}
\hline \multirow[b]{3}{*}{ Month } & \multicolumn{3}{|c|}{2016} & \multicolumn{3}{|c|}{2017} & \multicolumn{3}{|c|}{2018} \\
\hline & \multicolumn{2}{|c|}{ Temperature $\left({ }^{\circ} \mathrm{C}\right)$} & \multirow[b]{2}{*}{ VPD $(\mathrm{kPa})$} & \multicolumn{2}{|c|}{ Temperature $\left({ }^{\circ} \mathrm{C}\right)$} & \multirow[b]{2}{*}{ VPD (kPa) } & \multicolumn{2}{|c|}{ Temperature $\left({ }^{\circ} \mathrm{C}\right)$} & \multirow[b]{2}{*}{ VPD $(\mathrm{kPa}$} \\
\hline & Min. & Max. & & Min. & Max. & & Min. & Max. & \\
\hline January & 0.4 & 10.8 & 0.31 & 5.5 & 16.2 & 0.42 & -1.4 & 10.2 & 0.34 \\
\hline February & 3.6 & 14.8 & 0.43 & 6.8 & 19.2 & 0.56 & 8.8 & 19.1 & 0.40 \\
\hline March & 9.4 & 21.4 & 0.70 & 7.4 & 19.6 & 0.74 & 5.3 & 17.4 & 0.56 \\
\hline April & 10.8 & 23.0 & 0.78 & 13.0 & 25.4 & 0.86 & 8.0 & 21.3 & 0.73 \\
\hline May & 14.5 & 27.3 & 0.98 & 14.6 & 27.1 & 0.86 & 17.4 & 28.2 & 0.77 \\
\hline June & 19.6 & 32.7 & 1.28 & 19.1 & 28.7 & 0.69 & 19.6 & 31.2 & 0.78 \\
\hline July & 21.5 & 34.2 & 1.25 & 20.7 & 32.0 & 0.83 & 20.8 & 30.8 & 0.76 \\
\hline August & 21.8 & 32.9 & 0.99 & 20.5 & 30.1 & 0.76 & 20.2 & 30.5 & 0.72 \\
\hline September & 18.8 & 31.0 & 1.15 & 16.3 & 28.1 & 0.77 & 20.6 & 30.9 & 0.81 \\
\hline October & 12.4 & 26.4 & 0.89 & 11.8 & 23.4 & 0.56 & 12.8 & 23.9 & 0.59 \\
\hline November & 6.7 & 20.9 & 0.73 & 6.6 & 18.7 & 0.38 & 4.2 & 14.7 & 0.24 \\
\hline December & 3.8 & 14.3 & 0.33 & 3.5 & 12.7 & 0.26 & 4.4 & 13.2 & 0.26 \\
\hline
\end{tabular}

\begin{tabular}{|c|c|c|c|c|c|c|c|c|}
\hline & \multicolumn{8}{|c|}{ DRIP } \\
\hline \multirow{4}{*}{$\begin{array}{l}\overline{\text { z }} \\
\text { ठ্ }\end{array}$} & 8.3 & 1.2 & 2.2 & 3.4 & 1.1 & 3.2 & 6.3 & 6.4 \\
\hline & 3.1 & 5.4 & 7.3 & 8.2 & 2.4 & 6.2 & 2.1 & 7.2 \\
\hline & 3.3 & 8.4 & 6.1 & 1.3 & 5.3 & 7.1 & 7.4 & 5.2 \\
\hline & 4.2 & 5.1 & 4.4 & 2.3 & 8.1 & 4.1 & 1.4 & 4.3 \\
\hline \multirow{4}{*}{ 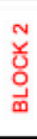 } & 3.3 & 2.3 & 2.1 & 8.3 & 1.1 & 6.2 & 1.4 & 5.3 \\
\hline & 6.4 & 8.4 & 7.3 & 3.4 & 7.4 & 7.2 & 1.3 & 1.2 \\
\hline & 4.4 & 3.2 & 6.3 & 2.4 & 8.2 & 5.2 & 8.1 & 5.4 \\
\hline & 7.1 & 2.2 & 5.1 & 4.2 & 4.3 & 3.1 & 4.1 & 6.1 \\
\hline \multirow{4}{*}{$\begin{array}{l}\text { m } \\
\text { 음 } \\
\text { 面 }\end{array}$} & 8.2 & 6.4 & 7.1 & 8.3 & 6.2 & 1.1 & 3.4 & 7.3 \\
\hline & 2.3 & 2.2 & 2.1 & 3.2 & 7.2 & 5.3 & 4.1 & 7.4 \\
\hline & 2.4 & 4.3 & 3.3 & 6.3 & 8.4 & 5.2 & 4.2 & 4.4 \\
\hline & 8.1 & 3.1 & 1.4 & 5.1 & 1.2 & 6.1 & 1.3 & 5.4 \\
\hline \multirow{3}{*}{ 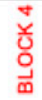 } & 5.3 & 1.1 & 2.3 & 8.1 & 5.1 & 6.2 & 6.3 & 7.1 \\
\hline & 5.2 & 7.3 & 3.3 & 2.1 & 8.3 & 4.2 & 1.3 & 7.2 \\
\hline & 6.1 & 1.2 & 2.2 & 4.1 & 3.1 & 8.2 & 3.2 & 4.3 \\
\hline
\end{tabular}

\begin{tabular}{|l|l|l|l|l|l|l|l|}
\hline \multicolumn{7}{|c|}{ MICRO-SPRINKLER } \\
\hline 8.4 & 3.1 & 6.4 & 2.1 & 7.2 & 6.1 & 4.1 & 1.1 \\
\hline 8.2 & 4.4 & 2.2 & 8.3 & 5.4 & 7.4 & 4.2 & 3.4 \\
\hline 3.2 & 5.2 & 6.3 & 7.1 & 1.3 & 4.3 & 1.2 & 5.3 \\
\hline 3.3 & 2.4 & 8.1 & 6.2 & 7.3 & 1.4 & 5.1 & 2.3 \\
\hline 7.3 & 6.3 & 6.1 & 7.1 & 8.3 & 6.2 & 8.2 & 1.2 \\
\hline 2.3 & 2.4 & 7.2 & 3.2 & 8.4 & 3.3 & 5.3 & 3.4 \\
\hline 3.1 & 4.4 & 4.3 & 4.2 & 5.2 & 1.4 & 5.1 & 2.2 \\
\hline 7.4 & 1.1 & 5.4 & 8.1 & 1.3 & 4.1 & 6.4 & 2.1 \\
\hline 3.2 & 1.2 & 7.1 & 4.1 & 3.1 & 3.3 & 6.2 & 6.1 \\
\hline 8.1 & 5.3 & 6.4 & 5.1 & 4.3 & 8.3 & 8.2 & 1.4 \\
\hline 2.4 & 7.3 & 6.3 & 8.4 & 1.1 & 3.4 & 4.4 & 2.2 \\
\hline 2.1 & 1.3 & 5.2 & 5.4 & 4.2 & 2.3 & 7.2 & 7.4 \\
\hline 4.2 & 8.2 & 8.1 & 6.1 & 8.3 & 6.2 & 7.3 & 2.3 \\
\hline 3.1 & 4.1 & 1.1 & 1.2 & 5.2 & 7.1 & 7.2 & 5.1 \\
\hline 2.2 & 3.3 & 4.3 & 3.2 & 5.3 & 1.3 & 2.1 & 6.3 \\
\hline
\end{tabular}

\begin{tabular}{|c|c|c|}
\hline Combination & Irrigation & $\begin{array}{c}\text { Fertilizer } \\
\text { level }\end{array}$ \\
\hline 1 & Irrigated & $25 \%$ \\
\hline 2 & Irrigated & $50 \%$ \\
\hline 3 & Irrigated & $100 \%$ \\
\hline 4 & Irrigated & $200 \%$ \\
\hline 5 & Non-irrigated & $25 \%$ \\
\hline 6 & Non-irrigated & $50 \%$ \\
\hline 7 & Non-irrigated & $100 \%$ \\
\hline 8 & Non-irrigated & $200 \%$ \\
\hline
\end{tabular}

Fig. 1. Experimental design. Each block had two areas (irrigation systems), one with drip and another with microsprinkler irrigation. Within each block, there were four sub-replications of each treatment combination for each area, except block four, which only had three sub-replications. Only one sub-replication was chosen for data collection in a given year, with the exception of canopy volume and TCSA in 2016 when all plants were measured. Therefore, the experiment had 64 experimental units $(8$ treatment combinations $\times 2$ irrigations systems $\times 4$ blocks $)$.

(VWC) data every $20 \mathrm{~min}$. Based on the average VWC readings of the four sensors within each fertilizer level/irrigation system combination, solenoid valves were turned on as needed to keep the VWC values above the irrigation thresholds set as follows: 1) Irrigation off from January to early-May; 2) VWC threshold of $25 \%$ from early-May to earlyAugust; 3) VWC threshold of $20 \%$ from early-August to mid-September; 4) VWC threshold of $15 \%$ from mid-September to late-September; and 5) irrigation off from late-September to December. These thresholds were based on soil moisture release curves for the specific soil type at the location.

The experimental field was divided in four quadrants, and one soil sample was taken in each quadrant center-point, at a $30 \mathrm{~cm}$ depth. The soil moisture release curves of the four samples were determined through the evaporative method (HYPROP, Meter Group). After analyzing the four samples separately, the HYPROP-VIEW Software (Meter Group) was used to analyze all four samples together, to generate one soil moisture release curve for the whole experimental area. The results of the analysis estimated a field capacity $(6 \mathrm{kPa})$ of $29.4 \% \mathrm{VWC}$ and a permanent wilting point (PWP) $(1500 \mathrm{kPa})$ of $19.1 \%$ VWC. However, the evaporative method has limitations in establishing the dry end of the moisture-release curve. The real PWP is likely below the $19.1 \%$. We aimed to have the VWC of the soil around the midpoint between the field capacity and the permanent wilting point during the most active growing period of the trees (spring and summer), and lower values of soil VWC toward the fall season. Due to lightning damage, the Sensorweb network was inactivated from 28 July 2017 until the end of the 2017 season and from 10 Aug. 2018 until 6 Sept. 2018. During these periods, VWC was monitored; however, no irrigation was needed because of the frequent rain (Table 2) linked with the reduction in VWC threshold in early-August. Starting in Mar. 2017, VWC of nonirrigated plots was recorded every 60 min, using VWC sensors (10HS, Meter Group) placed at 20 and $40 \mathrm{~cm}$ depths and distant $\approx 30 \mathrm{~cm}$ from the trunk, connected to data loggers (EM5b, Meter Group). Irrigation volume was measured using flow meters for 
Table 2. Precipitation (mm) from January to December in 2016, 2017, and 2018 and the historic normal (average from 1981 to 2010) at the Dempsey Farm, Griffin, GA.

\begin{tabular}{|c|c|c|c|c|c|c|c|c|c|c|c|c|c|}
\hline & Jan. & Feb. & Mar. & Apr. & May & June & July & Aug. & Sept. & Oct. & Nov. & Dec. & Total \\
\hline$\overline{2016}$ & 110 & 125 & 66 & 174 & 67 & 77 & 66 & 69 & 159 & 1 & 69 & 159 & 754 \\
\hline 2017 & 247 & 66 & 53 & 97 & 91 & 194 & 91 & 112 & 130 & 207 & 28 & 79 & 952 \\
\hline 2018 & 103 & 98 & 133 & 118 & 145 & 134 & 103 & 106 & 84 & 132 & 164 & 267 & 940 \\
\hline $1981-2010$ & 112 & 104 & 146 & 113 & 96 & 96 & 150 & 131 & 91 & 83 & 99 & 99 & 947 \\
\hline
\end{tabular}

all irrigation events. Drip irrigation delivered an average of $3065 \mathrm{~L} /$ tree across fertilizer treatments for the 3 years of experiment, whereas microsprinkler irrigation delivered $4743 \mathrm{~L} /$ tree. Nonirrigated trees received water only from rain events.

Four fertilization levels were tested (referred as $25 \%, 50 \%, 100 \%$, and $200 \%$ ). The amount of nitrogen in each level was as follows: $16,33,65$, and $129 \mathrm{~kg} \cdot \mathrm{ha}^{-1} \mathrm{~N}$ for 1-year-old trees; 23, 48, 95, and $191 \mathrm{~kg} \cdot \mathrm{ha}^{-1}$ $\mathrm{N}$ for 2-year-old trees; and 24, 49, 98, and $195 \mathrm{~kg} \cdot \mathrm{ha}^{-1} \mathrm{~N}$ for 3-year-old trees. The current recommended levels for 1-, 2-, and 3 -year-old trees are 65,95 , and $98 \mathrm{~kg} \cdot \mathrm{ha}^{-1} \mathrm{~N}$, respectively (referred as $100 \%$ in this experiment). Granular fertilizer was applied by hand: one application of $10.0 \mathrm{~N}-4.4 \mathrm{P}-$ $8.3 \mathrm{~K}$ (in March) and two applications of $15.5 \mathrm{~N}-0 \mathrm{P}-0 \mathrm{~K}$ (in May and July) for 1- and 2-year-old trees; and one application of $10.0 \mathrm{~N}-4.4 \mathrm{P}-8.3 \mathrm{~K}$ (in March) and one application of $15.5 \mathrm{~N}-0 \mathrm{P}-0 \mathrm{~K}$ (in August) for 3 year-old trees. The fertilizer applications followed the recommendations of the Southeastern Peach, Nectarine, and Plum Pest Management and Culture Guide (Horton et al., 2015).

Variables measured. Data were collected from a total of 64 trees, comprising four replications (blocks) of the 16 treatment combinations of: 1) irrigation levels (irrigated vs. nonirrigated trees); 2) irrigation systems (drip- vs. microsprinkler-irrigated trees); and 3) fertilizer levels (25\%, 50\%, $100 \%$, and $200 \%$ ).

Mid-day leaf water potential was assessed in July 2016. Midday stem water potential was measured in Aug. 2016; May, June, July, and Oct. 2017; and June, July, and Oct. 2018 by using a pressure chamber (1505D-EXP; PMS Instrument Company, Albany, OR). For the stem water potential measurements, a fully developed leaf for each data tree was chosen and covered with an aluminum foil bag for $\approx 20 \mathrm{~min}$ before measurement to allow the water potential of the leaf to equilibrate with the water potential of the tree stem/trunk, following the equipment's manual. The leaf was then detached from the tree while inside the aluminum bag and placed within the pressure chamber for measurements. For leaf water potential, no aluminum bag was used. All measurements were conducted around solar noon, on a clear, sunny day.

Photosynthetic net assimilation $\left(\mathrm{A}_{\mathrm{n}}\right)$ was measured once a month in June, July, and Aug. 2016; June, July, Aug., and Oct. 2017; and June, July, and Oct. 2018 using a portable photosynthesis system (LI-6400XT; LI-
COR, Lincoln, NE) equipped with a red/blue LED light source to maintain the photosynthetic photon flux density constant at the leaf $\left(1000 \mu \mathrm{mol} \cdot \mathrm{m}^{-2} \cdot \mathrm{s}^{-1}\right)$. A constant $\mathrm{CO}_{2}$ concentration of $400 \mu \mathrm{mol} \cdot \mathrm{mol}^{-1}$ was used in the chamber with leaf temperature and chamber humidity set to ambient. A fully developed leaf for each data tree was chosen, clamped in the leaf cuvette, and measured around solar noon. Concomitantly, leaf transpiration (E) was measured by the system, and water use efficiency at the leaf level (WUE) was estimated by dividing $A_{n}$ by E. Measurements were performed on a clear, sunny day, but not at the same day as water potential measurements.

Flower bud development was visually assessed weekly during the budbreak period (Mar. to Apr. 2017 and Feb. to Mar. 2018). Each data tree received one value representative to the average flower bud stage of the whole tree for each week of measurement. Flower bud stages were as follows: $1=$ Dormant, 2 = Bud Swell, $3=$ Green Calix, $4=$ Red Calix, $5=$ First Pink, $6=$ First Bloom, $7=$ Full Bloom, and $8=$ Post Bloom (adapted from Washington State University, n.d.). These stages correlate to the Baggiolini codes (Baggiolini, 1980) as follows: $1=\mathrm{A}, 2=\mathrm{B}, 3$ and $4=\mathrm{C}, 5=\mathrm{D}, 6=\mathrm{E}, 7=\mathrm{F}$, and $8=\mathrm{G}$ and $\mathrm{H}$ (Baggiolini codes do not differentiate stages 3 and 4, and our scale does not have two stages after full bloom).

Trunk cross-sectional area (TCSA) was assessed in Sept. 2016, Oct. 2017, and Oct. 2018 , by measuring the in-row and acrossrow trunk diameters at $15 \mathrm{~cm}$ above the soil surface with a caliper. The TCSA was calculated as $\pi \times[$ (in-row trunk diameter + acrossrow trunk diameter) $/ 4]^{2}$.

Canopy volume (CV), as the volume of a cone, was based on tree height and in-row and across-row canopy diameters in Sept. 2016, Oct. 2017, and Oct. 2018, using the formula $\mathrm{CV}=\pi \times[$ (in-row canopy diameter + acrossrow canopy diameter) $/ 4]^{2} \times($ tree height $/ 3)$.

Fruit yield was assessed in July 2017 and July 2018 based on three hand-harvests (6, 14, and 25 July 2017; and 5, 10, and 16 July 2018). Ripe fruit was hand-harvested and separated into commercial and noncommercial yield. Noncommercial fruit comprised of small, damaged, and/or misshapen fruit. Only the results of commercial yield are reported. Additionally, fruit yield efficiency was calculated by dividing commercial yield per tree by the trunk cross sectional area in 2017 and 2018.

Statistical analysis. SAS 9.4 (SAS Institute Inc., Cary, NC) was used to compare treatment means and interactions, using
PROC GLIMMIX. Means were separated using Tukey's honestly significant difference test with significance level at $P \leq 0.05$.

\section{Results}

The VWC of the soil is shown in Figs. 2 4. In 2016 (Fig. 2), irrigation was done manually from 14 May to 22 June, the period when the automated irrigation system was being tested. After that, the VWC thresholds were set in the software and the irrigation was controlled automatically until 19 Sept., when it was ended for the season. In 2017 (Fig. 3), automatic irrigation started on 12 May and kept working until 28 July, when the system was damaged by a lightning strike, ending the automatic irrigation for the season. In 2018 (Fig. 4), irrigation was activated on 7 May and worked until 7 Aug., when it was damaged by a storm, deactivating the system. The automatic irrigation resumed on 6 Sept. and worked for 15 more days until the system was ended for the season in late September. During the periods when the automatic system was deactivated because of storm/lightning strike, irrigation was done manually if the soil VWC data were available and below the thresholds. If the VWC data were not available, irrigation was not activated. The irrigation system kept the soil VWC above the thresholds established for the sensor-based irrigation. In 2016, we did not collect soil VWC data of the nonirrigated trees; however, data from leaf and stem water potential, $A_{n}$, and WUE prove that nonirrigated trees were negatively affected by drought stress. In 2017 and 2018 rain events were frequent. Data from water potential, $A_{n}$, and WUE, indicate that the trees did not experience drought stress during those 2 years (results shown in the following).

Leaf water potential was lower in nonirrigated trees in comparison with irrigated trees in July $2016(P<0.001)$. Similar results were found in Aug. $2016(P<0.001)$ for stem water potential. During the 2017 and 2018 seasons, no differences between irrigated vs. nonirrigated trees were reported for most of the evaluation dates. The exceptions were May $2017(P=0.019)$ and July $2018(P<$ $0.001)$, when nonirrigated trees had lower stem water potential than irrigated trees (Table 3).

Comparisons of water potential between drip- vs. microsprinkler-irrigated trees showed mixed results. No differences between these treatments were found in 2016 and early 2017. In Oct. 2017 and 2018, dripirrigated trees had lower stem water potential than microsprinkler-irrigated trees $(P=0.004$ 


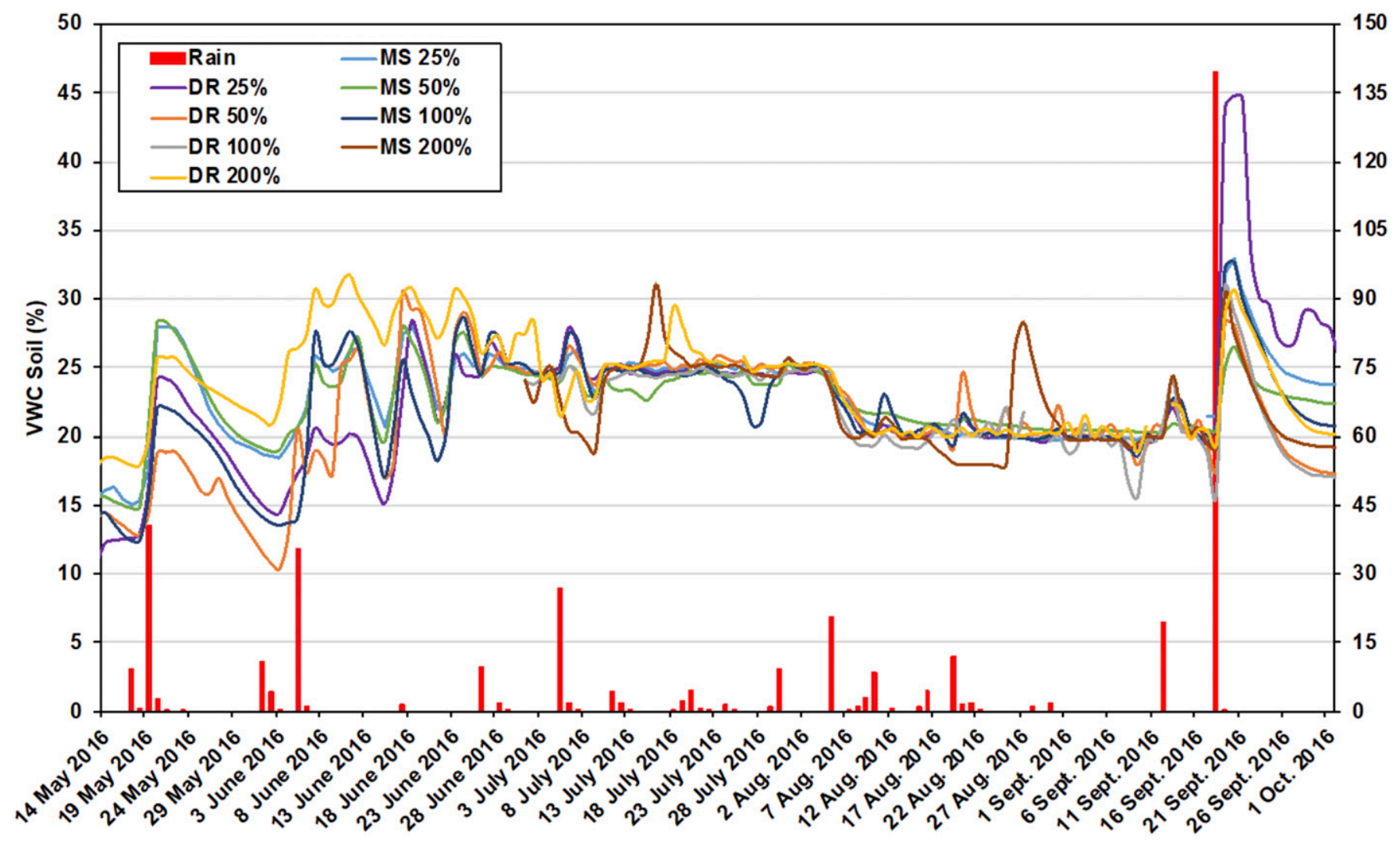

Fig. 2. Soil volumetric water content (VWC) in 2016 for the different combinations of drip (DR) and microsprinkler (MS) irrigation with different fertilizer levels $(25 \%, 50 \%, 100 \%$, and $200 \%)$. Rain events are shown as vertical bars. From 14 May 2016 to 22 June 2016, the irrigation system was being tested and the irrigation was controlled by hand, trying to keep the VWC above 25\%. After 23 June 2016, the automated irrigation network was turned on, following the thresholds established (early-May to early-August: VWC threshold of 25\%; early-August to mid-September: VWC threshold of 20\%; mid-September to late-September: VWC threshold of 15\%; late-September to December: irrigation off). Values are average of four sensors (two at $20 \mathrm{~cm}$ and two at $40 \mathrm{~cm}$ depth).

and 0.017 , respectively). However, the opposite was found in June $2018(P=0.034)$. Different fertilizer treatments had little effect on water potential. In Oct. 2017 and July 2018 , trees receiving $200 \%$ fertilizer had the lowest stem water potential, followed by trees receiving $100 \%$ and $50 \%$ fertilizer, and trees receiving $25 \%$ fertilizer had the highest water potential $(P=0.039$ and 0.005 , respectively) (Table 3 ). Interactions between irrigation levels and fertilizer levels were seen in Aug. $2016(P=0.049)$ and June $2017(P=0.015)$, and between irrigation system and fertilizer level $(P=0.011)$. However, the interactive effects were not consistent throughout the study (Table 3 ).

Photosynthetic net assimilation was measured during the same period (but not the same day) as leaf and stem water potential, from late spring through summer. In June, July, and Aug. 2016, $\mathrm{A}_{\mathrm{n}}$ of irrigated trees was higher than $A_{n}$ of nonirrigated trees (Table 4). Differences between drip- and microsprinkler-irrigated trees were reported only in June 2017 , with drip-irrigated trees having greater $A_{n}$ than microsprinkler-irrigated trees $\left(18.3\right.$ vs. $\left.16.1 \mu \mathrm{mol} \cdot \mathrm{m}^{-2} \cdot \mathrm{s}^{-1}, P=0.018\right)$. Differences among fertilizer treatments were significant only in Oct. $2018(P=0.01)$, when trees receiving $25 \%$ of fertilizer had the greatest $A_{n}\left(13.7 \mu \mathrm{mol} \cdot \mathrm{m}^{-2} \cdot \mathrm{s}^{-1}\right)$ and the trees receiving $200 \%$ of fertilizer had the lowest $A_{n}\left(11.6 \mu \mathrm{mol} \cdot \mathrm{m}^{-2} \cdot \mathrm{s}^{-1}\right)$ (Table 4). In Aug. 2016 there was an interaction between irrigation system and fertilizer treatments $(P=0.034)$. Trees with microsprinkler irrigation had greater $A_{n}$ when receiving $100 \%$ or $200 \%$ of fertilizer $\left(18.7\right.$ and $19.0 \mu \mathrm{mol} \cdot \mathrm{m}^{-2} \cdot \mathrm{s}^{-1}$, respectively) than trees receiving $25 \%$ or $50 \%$ of fertilizer (13.3 and $13.7 \mu \mathrm{mol} \cdot \mathrm{m}^{-2} \cdot \mathrm{s}^{-1}$, respectively); however, drip-irrigated trees had similar $A_{n}$ in all fertilization treatments, $\approx 20.3$ $\mu \mathrm{mol} \cdot \mathrm{m}^{-2} \cdot \mathrm{s}^{-1}$ (Table 4 ).

Nonirrigated trees had greater WUE than irrigated trees in June, July, and Aug. 2016, and June and July 2017. In July 2016, microsprinkler-irrigated trees had greater WUE than drip-irrigated trees (4.1 vs. 3.3 $\mathrm{mmol} \cdot \mathrm{mol}^{-1}, P=0.002$ ) (Table 4 ). No differences were found among the different fertilizer levels, except for Oct. $2018(P=0.02)$, when trees receiving $200 \%$ of fertilizer had the highest WUE $\left(3.3 \mathrm{mmol} \cdot \mathrm{mol}^{-1}\right)$ and the trees receiving $50 \%$ of fertilizer had the lowest WUE (3.0 $\left.\mathrm{mmol} \cdot \mathrm{mol}^{-1}\right)$ (Table 4). Interactions of irrigation system and fertilizer treatments $(P<0.001)$ in Aug. 2016 and irrigation levels and fertilizer levels $(P=0.044)$ in Oct. 2017 were found, but they were not consistent throughout the experiment (Table 4).

Flower bud stage development followed a sigmoidal pattern in 2017 with bud swell starting in the first week of March. Bud progression for irrigated trees was delayed in comparison with nonirrigated trees on the first 4 evaluation days (10-31 Mar.). On the fifth and sixth evaluation days ( 7 and 14 Apr.), no differences were found between irrigation levels (Table 5). Throughout the budbreak period, no differences were found between irrigation systems or among fertilization levels, except an interaction between irrigation levels and fertilizer levels on 31 Mar. $(P=0.05)$. Nonirrigated trees had similar flower bud stage regardless of the fertilizer treatment; however, irrigated trees receiving $100 \%$ or $200 \%$ fertilizer had more advanced flower bud stage than trees receiving $25 \%$ or $50 \%$ fertilizer. In 2018 , there were no treatment effects on budbreak progression (Table 5).

Irrigated trees had greater TCSA in all 3 years (Table 6). However, for the fertilizer and irrigation system treatments, different results were found in different years. In Sept. 2016, there was a significant interaction among irrigation system and fertilization treatments $(P=0.003)$, with trees receiving $200 \%$ of fertilizer having greater TCSA than the other fertilizer treatments when microsprinklerirrigated $\left(34.3\right.$ vs. $\left.\approx 25.8 \mathrm{~cm}^{2}\right)$ and no differences were found among fertilization treatments when drip-irrigated $\left(\overline{\mathrm{x}}=31.5 \mathrm{~cm}^{2}\right)$. In Oct. 2017, no differences were found when comparing irrigation systems or fertilization treatments (Table 6). In Oct. 


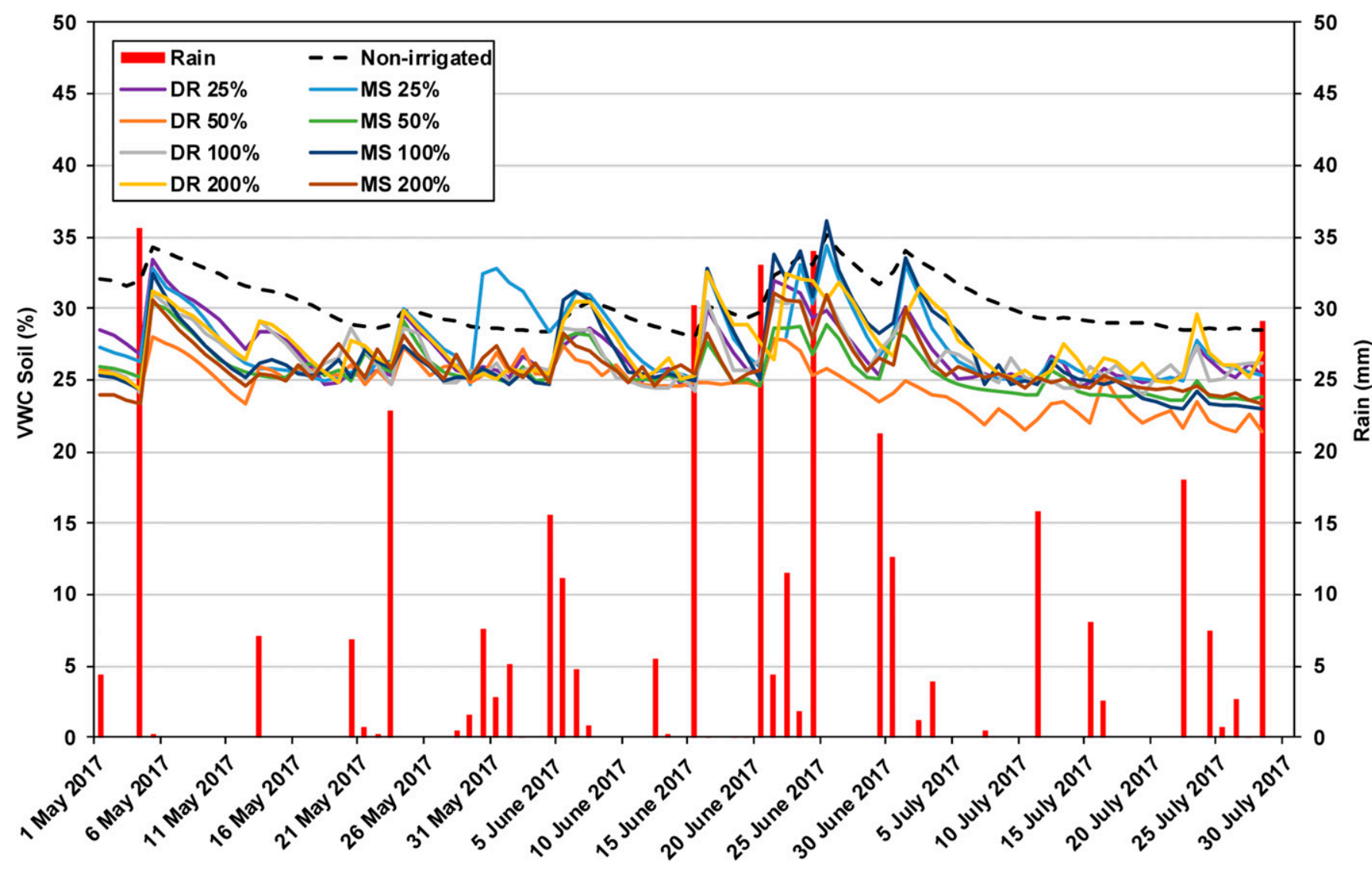

Fig. 3. Soil volumetric water content (VWC) in 2017 for the nonirrigated treatments and for the different combinations of drip (DR) and microsprinkler (MS) irrigation with different fertilizer levels $(25 \%, 50 \%, 100 \%$, and $200 \%)$. Rain events are shown as vertical bars. The automated irrigation network was activated 12 May 2017, with the intent of following the thresholds established (early-May to early-August: VWC threshold of 25\%; early-August to mid-September: VWC threshold of $20 \%$; mid-September to late-September: VWC threshold of $15 \%$; late-September to December: irrigation off). The system was damaged and deactivated after 28 July 2017 because of a lightning strike. For the irrigated treatments, values are average of four sensors (two at $20 \mathrm{~cm}$ and two at $40 \mathrm{~cm}$ depth). For the nonirrigated, values are average of 32 sensors (16 at $20 \mathrm{~cm}$ and 16 at $40 \mathrm{~cm}$ depth).

2018, drip-irrigated trees had greater TCSA than microsprinkler-irrigated trees $(138.3$ vs. $115.1 \mathrm{~cm}^{2}, P=0.018$ ), and no differences were found among fertilization treatments (Table 6).

Canopy volume results followed a similar trend as TCSA when comparing irrigated vs. nonirrigated trees. Irrigated trees had greater canopy volume during all 3 years (Table 6). For the comparisons among fertilization and irrigation system treatments, different years resulted in different responses. In Sept. 2016, there was an interaction among fertilization and irrigation system treatments $(P<0.001)$, with no differences among fertilization treatments when trees were drip-irrigated. However, for microsprinkler-irrigated trees, the highest fertilization treatment resulted in greater canopy volume. In Oct. 2017 and 2018 , no differences were found among fertilization treatments or irrigation systems (Table 6).

The fruit yield was analyzed in 2017 and 2018 , corresponding to the first and second year of fruit production for this orchard. The commercial yield of 2017 was increased by irrigation (13.4 vs. $10.9 \mathrm{~kg} /$ tree for nonirrigated trees, $P=0.037$ ), while different irrigation systems and fertilization treatments did not induce any differences (Table 6). In contrast, in 2018, the commercial yield was unaffected by irrigation levels or fertilization treatments. However, within the irrigated trees, microsprinkler-irrigated trees had a greater commercial yield than dripirrigated trees $(19.7$ vs. $10.4 \mathrm{~kg} /$ tree, $P=$ 0.021 ) (Table 6). Fruit yield efficiency was unaffected by irrigation levels or fertilization treatments in either 2017 or 2018. Microsprinkler-irrigated trees had similar fruit yield efficiency to drip-irrigated trees in $2017\left(0.21\right.$ vs. $0.17 \mathrm{~kg}$ of fruit $/ \mathrm{cm}^{2}$ of TCSA) but greater fruit yield efficiency in 2018 ( 0.19 vs. $0.17 \mathrm{~kg}$ of fruit $/ \mathrm{cm}^{2}$ of TCSA) (data not shown).

\section{Discussion}

Below-historical-average rainfall resulted in low leaf and stem water potential of nonirrigated trees in 2016, indicating that nonirrigated trees had limited soil water availability. In 2017 and 2018, because of rainfall similar to the historical average, irrigated and nonirrigated trees experienced similar soil water availability. In 2017, the VWC readings of the nonirrigated trees were slightly higher on average than those of irrigated trees, perhaps because the sensors for nonirrigated trees had been recently installed. The soil near the sensors had been disturbed, possibly allowing for more water to be present around the sensors. This difference was not present in 2018, when the sensors were well-established in the soil.

Leaf and stem water potential are related to the soil VWC and weather conditions (Mahhou et al., 2005). Previous research with peach trees (Mahhou et al., 2005; Mirás-Avalos et al., 2013; Rahmati et al., 2015; Tormann, 1986) estimated that midday stem water potential values above $-1.0 \mathrm{MPa}$ are considered "no stress," whereas values around -1.5 and $-2.0 \mathrm{MPa}$ correspond to "moderate stress" and "severe stress," respectively. Our results of leaf and stem water potential varied across years, like the results reported by Abrisqueta et al. (2015). In 2016, the low rain and soil VWC likely limited treeavailable water, inducing the severe stress measured in July and August for nonirrigated trees, agreeing with results of leaf and stem water potential reported by Goldhamer et al. (1999). Despite the lack of precipitation right before the 2017 growing season (February to April), precipitation was close the historical average when the trees were actively growing (May to August). This resulted in stem water potential values not indicative of drought, for irrigated and nonirrigated trees. Like 2017, 2018 had rainfall close to the historical average from 


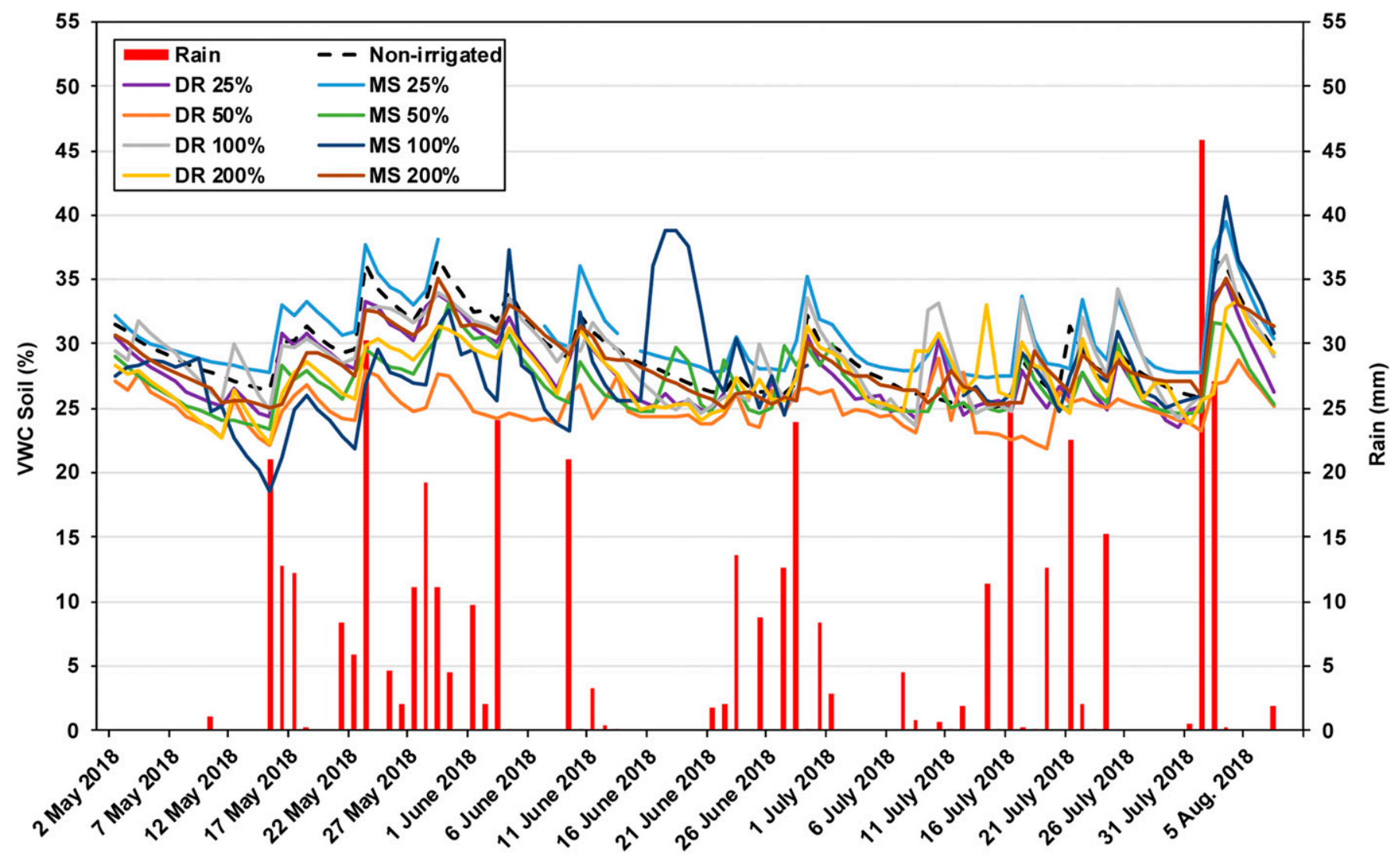

Fig. 4. Soil volumetric water content (VWC) in 2018 for the nonirrigated treatments and for the different combinations of drip (DR) and microsprinkler (MS) irrigation with different fertilizer levels $(25 \%, 50 \%, 100 \%$, and $200 \%)$. Rain events are shown as vertical bars. The automated irrigation network was activated on 7 May 2018, with the intent of following the thresholds established (early-May to early-August: VWC threshold of 25\%; early-August to mid-September: VWC threshold of 20\%; mid-September to late-September: VWC threshold of $15 \%$; late-September to December: irrigation off). However, the system was damaged and the data were not recorded from 8 Aug. 2018 to 5 Sept. 2018. For the irrigated treatments, values are average of four sensors (two at a $20 \mathrm{~cm}$ depth and two at a $40 \mathrm{~cm}$ depth). For the nonirrigated, values are average of 32 sensors (16 at $20 \mathrm{~cm}$ and 16 at a $40 \mathrm{~cm}$ depth).

Table 3. Effects of irrigation levels, irrigation systems, and fertilizer levels on leaf and stem water potential of 'Julyprince' peaches in 2016, 2017 , and 2018.

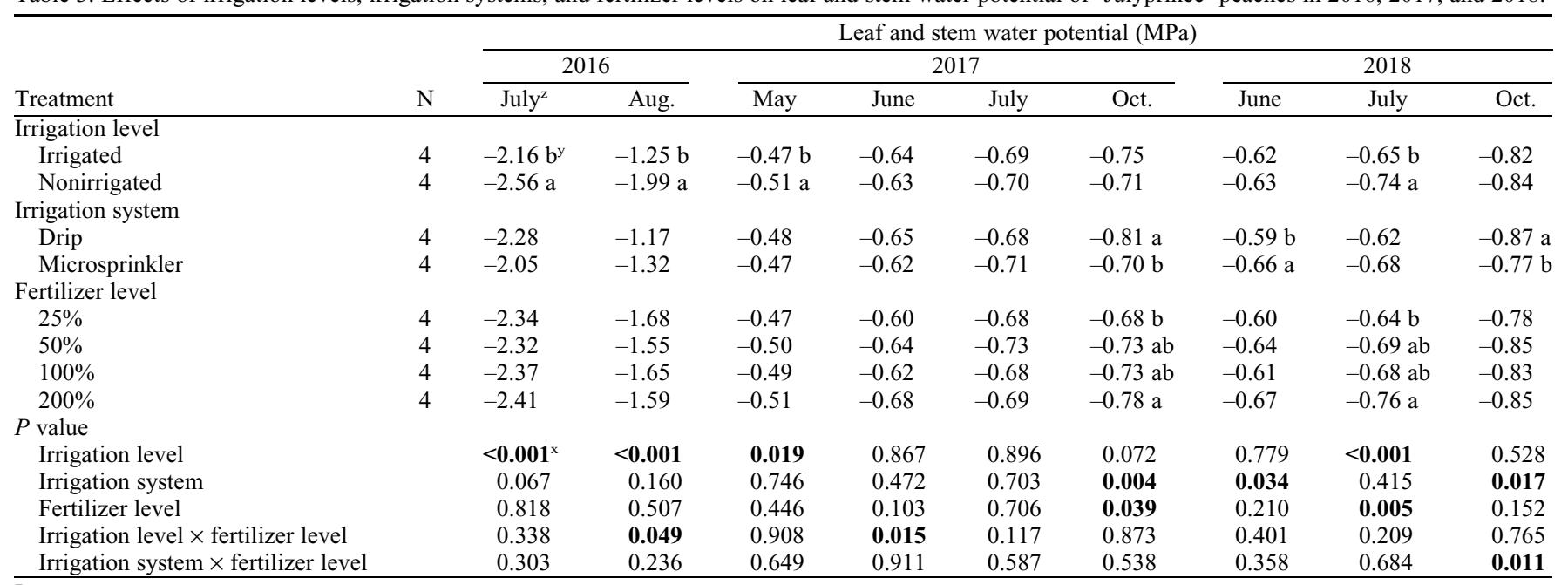

${ }^{\mathrm{z}}$ Leaf water potential was measured in July 2016 only. The data for other months are stem water potential.

${ }^{\mathrm{y}}$ Means followed by the same letter within a column and treatment effect are not significantly different by Tukey's honestly significant difference test, $P \leq 0.05$.

Means without letters indicate nonsignificant differences.

${ }^{\mathrm{x}}$ Bold values indicate significant difference.

January through August, not resulting in drought stress for either irrigated or nonirrigated trees. Some statistical differences were found in 2017 and 2018, but they were not consistent over time and do not have a biological significance, be- cause the water potential values are all within the "no stress" range.

During 2016 drought conditions, a lack of irrigation reduced $\mathrm{A}_{\mathrm{n}}$ by $\approx 40 \%$, agreeing with earlier reports (Dichio et al., 2007; Goldhamer et al., 1999; Mahhou et al., 2005; Mercier et al., 2009). In August of 2016, drip-irrigated trees displayed greater assimilation than microsprinkler-irrigated trees. Both drip and microsprinkler treatments were set to keep the 
Table 4. Effects of irrigation levels, irrigation systems, and fertilizer levels on photosynthetic assimilation ( $\mathrm{A}_{\mathrm{n}}$ ) and water use efficiency (WUE) of 'Julyprince' peaches in 2016, 2017, and 2018 .

\begin{tabular}{|c|c|c|c|c|c|c|c|c|c|c|c|}
\hline \multirow[b]{3}{*}{ Treatment } & \multirow[b]{3}{*}{$\mathrm{N}$} & \multicolumn{10}{|c|}{$\mathrm{A}_{\mathrm{n}}\left(\mu \mathrm{mol} \mathrm{CO} 2 / \mathrm{m}^{2} / \mathrm{s}\right)$} \\
\hline & & \multicolumn{3}{|c|}{2016} & \multicolumn{4}{|c|}{2017} & \multicolumn{3}{|c|}{2018} \\
\hline & & June & July & Aug. & June & July & Aug. & Oct. & June & July & Oct. \\
\hline \multicolumn{12}{|l|}{ Irrigation level } \\
\hline Irrigated & 4 & $14.9 \mathrm{a}^{\mathrm{z}}$ & $14.3 \mathrm{a}$ & $18.3 \mathrm{a}$ & 17.2 & 16.3 & 12.4 & 11.0 & 15.3 & 18.5 & 13.1 \\
\hline Nonirrigated & 4 & $6.7 \mathrm{~b}$ & $8.2 \mathrm{~b}$ & $13.4 \mathrm{~b}$ & 16.4 & 16.5 & 12.6 & 11.7 & 16.0 & 18.2 & 12.5 \\
\hline \multicolumn{12}{|l|}{ Irrigation system } \\
\hline Drip & 4 & 15.1 & 13.8 & $20.3 \mathrm{a}$ & $18.3 \mathrm{a}$ & 16.1 & 11.9 & 11.0 & 15.3 & 18.9 & 13.2 \\
\hline Microsprinkler & 4 & 14.7 & 14.8 & $16.2 \mathrm{~b}$ & $16.1 \mathrm{~b}$ & 16.4 & 12.8 & 11.0 & 15.3 & 18.1 & 13.0 \\
\hline \multicolumn{12}{|l|}{ Fertilizer level } \\
\hline $25 \%$ & 4 & 10.7 & 10.1 & 14.8 & 17.3 & 16.2 & 13.7 & 11.2 & 16.0 & 18.7 & $13.7 \mathrm{a}$ \\
\hline $50 \%$ & 4 & 10.5 & 11.3 & 15.6 & 16.4 & 15.8 & 12.3 & 10.0 & 16.0 & 18.4 & $13.2 \mathrm{ab}$ \\
\hline $100 \%$ & 4 & 10.1 & 10.9 & 16.3 & 16.9 & 17.4 & 12.1 & 11.8 & 15.2 & 18.4 & $12.8 \mathrm{ab}$ \\
\hline $200 \%$ & 4 & 11.9 & 12.6 & 16.6 & 16.7 & 16.0 & 11.8 & 12.3 & 15.3 & 17.9 & $11.6 \mathrm{~b}$ \\
\hline \multicolumn{12}{|l|}{$P$ value } \\
\hline Irrigation level & & $<\mathbf{0 . 0 0 1}^{\mathrm{y}}$ & $<0.001$ & $<0.001$ & 0.151 & 0.677 & 0.718 & 0.316 & 0.213 & 0.531 & 0.211 \\
\hline Irrigation system & & 0.511 & 0.377 & $<0.001$ & 0.018 & 0.771 & 0.500 & 0.993 & 0.983 & 0.154 & 0.785 \\
\hline Fertilizer level & & 0.099 & 0.173 & 0.306 & 0.689 & 0.060 & 0.086 & 0.094 & 0.627 & 0.551 & 0.010 \\
\hline Irrigation level $\times$ fertilizer level & & 0.496 & 0.826 & 0.161 & 0.713 & 0.659 & 0.832 & 0.474 & 0.730 & 0.462 & 0.356 \\
\hline \multirow[t]{3}{*}{ Irrigation system $\times$ fertilizer level } & & 0.175 & 0.063 & 0.034 & 0.838 & 0.650 & 0.614 & 0.500 & 0.669 & 0.930 & 0.924 \\
\hline & & \multicolumn{10}{|c|}{ WUE $\left(\mathrm{mmol} \cdot \mathrm{mol}^{-1}\right)$} \\
\hline & & \multicolumn{3}{|c|}{2016} & \multicolumn{4}{|c|}{2017} & \multicolumn{3}{|c|}{2018} \\
\hline Treatment & $\mathrm{N}$ & June & July & Aug. & June & July & Aug. & Oct. & June & July & Oct. \\
\hline \multicolumn{12}{|l|}{ Irrigation level } \\
\hline Irrigated & 4 & $3.5 \mathrm{~b}$ & $3.7 \mathrm{~b}$ & $5.8 \mathrm{~b}$ & $4.4 \mathrm{~b}$ & $2.9 \mathrm{~b}$ & 3.2 & 5.1 & 2.8 & 3.2 & 3.1 \\
\hline Nonirrigated & 4 & $5.1 \mathrm{a}$ & $4.9 \mathrm{a}$ & $7.4 \mathrm{a}$ & $4.6 \mathrm{a}$ & $3.1 \mathrm{a}$ & 3.1 & 5.0 & 2.9 & 3.1 & 3.1 \\
\hline \multicolumn{12}{|l|}{ Irrigation system } \\
\hline Drip & 4 & 3.6 & $3.3 \mathrm{~b}$ & 5.1 & 4.3 & 3.0 & 3.1 & 5.2 & 2.9 & 3.2 & 3.0 \\
\hline Microsprinkler & 4 & 3.3 & $4.1 \mathrm{a}$ & 6.5 & 4.5 & 2.9 & 3.2 & 5.1 & 2.7 & 3.1 & 3.2 \\
\hline \multicolumn{12}{|l|}{ Fertilizer level } \\
\hline $25 \%$ & 4 & 4.1 & 4.6 & 6.9 & 4.3 & 3.0 & 3.0 & 5.0 & 2.8 & 3.1 & $3.1 \mathrm{ab}$ \\
\hline $50 \%$ & 4 & 4.4 & 4.1 & 6.9 & 4.5 & 3.1 & 3.2 & 4.9 & 2.9 & 3.2 & $3.0 \mathrm{~b}$ \\
\hline $100 \%$ & 4 & 4.4 & 4.6 & 6.2 & 4.6 & 3.0 & 3.2 & 5.1 & 2.9 & 3.2 & $3.2 \mathrm{ab}$ \\
\hline $200 \%$ & 4 & 4.3 & 4.0 & 6.5 & 4.5 & 3.0 & 3.2 & 5.2 & 3.0 & 3.0 & $3.3 \mathrm{a}$ \\
\hline \multicolumn{12}{|l|}{$P$ value } \\
\hline Irrigation level & & $<0.001$ & $<0.001$ & $<0.001$ & 0.047 & 0.028 & 0.913 & 0.472 & 0.197 & 0.409 & 0.528 \\
\hline Irrigation system & & 0.123 & 0.002 & 0.052 & 0.253 & 0.058 & 0.386 & 0.707 & 0.364 & 0.059 & 0.312 \\
\hline Fertilizer level & & 0.470 & 0.141 & 0.482 & 0.151 & 0.593 & 0.405 & 0.506 & 0.077 & 0.401 & 0.020 \\
\hline Irrigation level $\times$ fertilizer level & & 0.953 & 0.584 & 0.161 & 0.925 & 0.698 & 0.664 & 0.044 & 0.456 & 0.935 & 0.159 \\
\hline Irrigation system $\times$ fertilizer level & & 0.061 & 0.135 & $<0.001$ & 0.819 & 0.258 & 0.101 & 0.062 & 0.233 & 0.314 & 0.051 \\
\hline
\end{tabular}

${ }^{\mathrm{z}}$ Means followed by the same letter within a column and treatment effect are not significantly different by Tukey's honestly significant difference test, $P \leq 0.05$. Means without letters indicate nonsignificant differences.

${ }^{\mathrm{y}}$ Bold values indicate significant difference.

volumetric water content of the soil above the same thresholds, which would suggest similar amounts of water in the soil, regardless of the irrigation system. One possible explanation for the difference in $\mathrm{A}_{\mathrm{n}}$ is how the systems delivered water to the soil and how the root system behaved. Drip irrigation delivers water to a smaller volume of soil, where the roots will concentrate. Microsprinklers create jets of water around the trunk, irrigating a greater volume of soil, where the roots will proliferate. Therefore, the root system of drip-irrigated trees likely is more concentrated in the wetted area, being more efficient at absorbing the applied irrigation water, a concept supporting work by Tagliavini et al. (1996). In 2017 and 2018, no consistent differences among treatments were found. Fertilizer levels did not induce changes in $A_{n}$, likely because the leaf nutritional levels were not negatively affected by the fertilizer levels (Casamali, 2019). Similarly, Pascual et al. (2016) did not find leaf nutritional differences among fertilizer treatments in two out of three evaluations.

Water use efficiency results differed among years. In 2016, and June and July 2017, nonirri- gated trees had higher WUE than irrigated trees, consistent with WUE data $\left(\mathrm{A}_{\mathrm{n}} /\right.$ stomatal conductance) reported by Haider et al. (2018). Belowaverage rainfall was present from 2016 until May 2017, increasing WUE of nonirrigated trees until July 2017. The 2018 growing season had aboveaverage rainfall, which resulted in no WUE differences for any irrigation treatments. Irrigation systems and fertilizer levels did not induce consistent WUE responses in the trees in all three seasons, a finding that agrees with results from a prior fertility study (Haider et al., 2018).

Flower budbreak progression differed in the 2 years of evaluation. There were differences among the treatments in the early stages of budbreak progression in 2017, mainly because of the presence or absence of irrigation. Budbreaking progression from bud swell to full bloom advanced faster in nonirrigated than in the irrigated trees. Flower buds opening in 2017 were induced and differentiated during Summer 2016, when rainfall was below average (Table 2), affecting the nonirrigated trees.

Drought stress can alter the hormonal and assimilate balance of trees, causing the accu- mulation of active substances, such as polyamines, which are linked to increased levels of floral initiation (Johnson et al., 1992). Greater flower initiation in 2016 during the drought stress likely resulted in a higher number of flower buds, resulting in an advanced budbreak progression. In contrast to 2017, 2018 bud development was similar in all treatments, possibly because the 2017 growing season had above-average rainfall (Table 2). Thus, the flower buds of the 2018 season differentiated in the absence of drought in 2017.

Over the 3-year period of research, irrigated trees had a larger trunk cross-sectional area and canopy volume than nonirrigated trees. The TCSA results agree with Layne et al. (2002), who also found greater TCSA in trees with irrigation, compared with rainfallonly treatment. Similarly, Goldhamer et al. (2002) found increased trunk diameter in irrigated trees vs. regulated deficit irrigation. For canopy volume, Boland et al. (2000) reported reduced canopy volume for trees grown under deficit irrigation.

An interaction between irrigation system and fertilization treatments was found in 
Table 5. Effects of irrigation levels, irrigation systems, and fertilizer levels on budbreak progression of 'Julyprince' peaches in 2017 and 2018.

\begin{tabular}{|c|c|c|c|c|c|c|c|}
\hline \multirow[b]{2}{*}{ Treatment } & \multirow[b]{2}{*}{$\mathrm{N}$} & \multicolumn{6}{|c|}{ Bud stage $2017^{z}$} \\
\hline & & 10 Mar. & 17 Mar. & 24 Mar. & 31 Mar. & 7 Apr. & 14 Apr. \\
\hline Irrigated & 4 & $2.0 \mathrm{~b}^{\mathrm{y}}$ & $2.4 \mathrm{~b}$ & $4.3 \mathrm{~b}$ & $6.6 \mathrm{~b}$ & 7.9 & 8.0 \\
\hline Drip & 4 & 1.9 & 2.4 & 4.6 & 6.6 & 7.9 & 8.0 \\
\hline Microsprinkler & 4 & 2.2 & 2.3 & 4.0 & 6.5 & 7.8 & 8.0 \\
\hline \multicolumn{8}{|l|}{ Fertilizer level } \\
\hline $100 \%$ & 4 & 2.4 & 2.7 & 4.8 & 6.9 & 8.0 & 8.0 \\
\hline $200 \%$ & 4 & 2.4 & 2.8 & 4.6 & 6.8 & 8.0 & 8.0 \\
\hline \multicolumn{8}{|l|}{$P$ value } \\
\hline Irrigation level & & $<0.001^{x}$ & $<0.001$ & 0.027 & 0.019 & 0.271 & 1.000 \\
\hline Irrigation system & & 0.108 & 0.299 & 0.102 & 0.587 & 0.564 & 1.000 \\
\hline Fertilizer level & & 0.744 & 0.692 & 0.597 & 0.823 & 0.357 & 1.000 \\
\hline Irrigation level $\times$ fertilizer level & & 0.691 & 0.159 & 0.217 & 0.050 & 0.680 & 1.000 \\
\hline Irrigated & 4 & 1.0 & 2.9 & 5.0 & 7.1 & 8.0 & \\
\hline Nonirrigated & 4 & 1.0 & 2.9 & 5.0 & 7.1 & 8.0 & \\
\hline \multicolumn{8}{|l|}{ Irrigation system } \\
\hline Drip & 4 & 1.0 & 2.8 & 5.0 & 7.1 & 8.0 & \\
\hline Microsprinkler & 4 & 1.0 & 2.9 & 5.0 & 7.0 & 8.0 & \\
\hline \multicolumn{8}{|l|}{ Fertilizer level } \\
\hline $25 \%$ & 4 & 1.0 & 3.0 & 5.0 & 7.0 & 8.0 & \\
\hline $50 \%$ & 4 & 1.0 & 2.8 & 5.0 & 7.1 & 8.0 & \\
\hline $100 \%$ & 4 & 1.0 & 2.8 & 5.0 & 7.1 & 8.0 & \\
\hline $200 \%$ & 4 & 1.0 & 2.8 & 5.0 & 7.1 & 8.0 & \\
\hline \multicolumn{8}{|l|}{$P$ value } \\
\hline Irrigation level & & 1.000 & 0.583 & 0.505 & 0.313 & 1.000 & \\
\hline Irrigation system & & 1.000 & 0.709 & 1.000 & 0.564 & 1.000 & \\
\hline Fertilizer level & & 1.000 & 0.312 & 0.929 & 0.737 & 1.000 & \\
\hline
\end{tabular}

${ }_{\mathrm{z}}$ Bud stages adapted from Washington State University (n.d.); 1 = Dormant, 2 = Bud Swell, 3 = Green Calix, 4 = Red Calix, 5 = First Pink, 6 = First Bloom, 7 = Full Bloom, and $8=$ Post Bloom.

${ }^{\mathrm{y}}$ Means followed by the same letter within a column and treatment effect are not significantly different by Tukey's honestly significant difference test, $P \leq 0.05$.

Means without letters indicate nonsignificant differences.

${ }^{\mathrm{x}}$ Bold values indicate significant difference.

Table 6. Effects of irrigation levels, irrigation systems, and fertilizer levels on trunk cross-sectional area (TCSA) and canopy volume in 2016, 2017, and 2018; and commercial yield of 'Julyprince' peaches in 2017 and 2018.

\begin{tabular}{|c|c|c|c|c|c|c|c|c|c|}
\hline \multirow[b]{2}{*}{ Treatment } & \multirow[b]{2}{*}{$\mathrm{N}$} & \multicolumn{3}{|c|}{ TCSA $\left(\mathrm{cm}^{2}\right)$} & \multicolumn{3}{|c|}{ Canopy volume $\left(\mathrm{m}^{3}\right)$} & \multicolumn{2}{|c|}{ Commercial yield (kg/tree) } \\
\hline & & Sept. 2016 & Oct. 2017 & Oct. 2018 & $\overline{\text { Sept. } 2016}$ & Oct. 2017 & Oct. 2018 & 2017 & 2018 \\
\hline Irrigated & 4 & $29.7 \mathrm{a}^{\mathrm{z}}$ & $70.1 \mathrm{a}$ & $126.7 \mathrm{a}$ & $4.5 \mathrm{a}$ & $10.9 \mathrm{a}$ & $17.8 \mathrm{a}$ & $13.4 \mathrm{a}$ & 15.1 \\
\hline \multicolumn{10}{|l|}{ Irrigation system } \\
\hline Drip & 4 & 31.5 & 72.5 & $138.3 \mathrm{a}$ & $4.7 \mathrm{a}$ & 11.5 & 19.1 & 15.0 & $10.4 \mathrm{~b}$ \\
\hline Microsprinkler & 4 & 28.0 & 67.7 & $115.1 \mathrm{~b}$ & $4.3 \mathrm{~b}$ & 10.4 & 16.5 & 11.7 & $19.7 \mathrm{a}$ \\
\hline \multicolumn{10}{|l|}{ Fertilizer level } \\
\hline $100 \%$ & 4 & 23.4 & 63.8 & 118.1 & $3.2 \mathrm{ab}$ & 10.4 & 17.4 & 11.2 & 13.0 \\
\hline $200 \%$ & 4 & 25.7 & 62.8 & 116.2 & $3.5 \mathrm{a}$ & 9.8 & 16.6 & 13.8 & 13.2 \\
\hline \multicolumn{10}{|l|}{$P$ value } \\
\hline Irrigation level & & $<0.001^{y}$ & $<0.001$ & $<0.001$ & $<0.001$ & $<0.001$ & 0.013 & 0.037 & 0.344 \\
\hline Irrigation system & & 0.056 & 0.306 & 0.018 & 0.017 & 0.112 & 0.071 & 0.097 & 0.021 \\
\hline Fertilizer level & & 0.088 & 0.715 & 0.523 & 0.014 & 0.341 & 0.621 & 0.264 & 0.725 \\
\hline Irrigation level $\times$ fertilizer level & & 0.211 & 0.502 & 0.621 & 0.659 & 0.547 & 0.380 & 0.620 & 0.795 \\
\hline
\end{tabular}

${ }^{\mathrm{z}}$ Means followed by the same letter within a column and treatment effect are not significantly different by Tukey's honestly significant difference test, $P \leq 0.05$.

Means without letters indicate nonsignificant differences.

${ }^{\mathrm{y}}$ Bold values indicate significant difference.

2016 for both TCSA and canopy volume; however, the results were not consistent during the 3 years of research. These results suggest that different irrigation systems and fertilizer treatments had little-to-no impact on TCSA and canopy volume of young peach trees in our experiment. These results agree with research done by Layne et al. (2002), who reported a small reduction in TCSA when reducing the fertilizer by $30 \%$, and with Olmstead et al. (2015) and Baldi et al. (2010), who found no differences in TCSA in 
response to different $\mathrm{N}$ levels. In our research, it appears that the highest fertilizer level induced greater tree growth in the first year of evaluation (larger canopy volume). However, the effect did not persist into years 2 and 3.

Commercial yield differed across treatments depending on the year. In 2017, irrigated trees had a higher yield than nonirrigated trees. In 2017, the precipitation was below the historical normal from February to May and during July (Table 2). Therefore, nonirrigated trees likely were negatively affected by drought during the fruit growth and development period, from mid-March to mid-July. Further, irrigated trees were larger than their nonirrigated counterparts, which may translate to more fruiting wood, eventually resulting in higher yield.

In 2018, the yield was unaffected by the irrigation level, but trees grown with microsprinkler irrigation had $89 \%$ higher yield than trees with drip irrigation. The effect of irrigation system on yield in 2018 was likely not a direct result of the irrigation system. An advective hard freeze affected the orchard in Mar. 2018, during bloom, and likely induced differences between the treatments. Because of the landscape topography of the orchard, the trees with drip irrigation received direct wind gusts, while the trees under microsprinkler irrigation were protected because of a hilltop (nonirrigated trees in the drip side were also affected, whereas the nonirrigated trees on the microsprinkler side were unaffected). This also explains differences between irrigations systems found for fruit yield efficiency.

Fertilizer treatments had no effect on fruit yield in either year, agreeing with Layne et al. (1996), who reported no differences in fruit yield in response to combinations of irrigation and fertilization. Similarly, Baldi et al. (2010) did not find differences in fruit yield between fertilized vs. nonfertilized trees in the first 2 years of fruit production, likely because there were enough nutrients in the soil to support the initial plant growth. However, fertilized trees had greater yield in the third year of fruit production, likely because the long-term lack of fertilization started to induce negative effects on the nonfertilized trees. Testing the effects of different fertilizer levels on peaches, Vashisth et al. (2017) reported inconclusive data on fruit yield, because the intermediate $\mathrm{N}$ treatment $(90$ $\mathrm{kg} \cdot \mathrm{ha}^{-1}$ per year) had greater yield than the 45 and $179 \mathrm{~kg} \cdot \mathrm{ha}^{-1}$ per year treatments, but similar yield to the 0 and $269 \mathrm{~kg} \cdot \mathrm{ha}^{-1}$ per year treatments.

Establishing irrigation in the first year of field planting showed benefits for young peach trees. Irrigated trees displayed greater growth with a larger canopy and trunk size, which opens the possibility of having higher yields if below-average rainfall is reported. Because of the drought stress that nonirrigated trees suffered in 2016, the negative effects carried over to the 2017 and 2018 seasons. Growth of nonirrigated trees did not catch up with that of irrigated trees after 3 years.

\section{Conclusions}

Irrigation systems (drip or microsprinkler) did not induce consistent differences across years of evaluation; however, drip irrigation was more efficient delivering water, resulting in $\approx 35 \%$ of water savings in comparison with microsprinkler irrigation. Like the irrigation systems, fertilizer treatments did not induce consistent responses, having little-to-no effect on growth or physiology of young peach trees. The long-term effect of reductions in fertilizer levels is yet to be determined.

Irrigation from the time of establishment can serve as insurance for peach growers, as it is beneficial during periods of drought, which are becoming more common in the southeastern United States. Greater tree growth and fruit yield can be achieved by irrigating trees from establishment. In contrast, current fertilizer levels can be reduced without negative impacts on peach tree growth and yield during the initial years of field establishment. Improved irrigation and fertilization in young peach trees will increase the efficiency and sustainability of peach production in the southeastern United States.

\section{Literature Cited}

Abrisqueta, I., W. Conejero, M. Valdés-Vela, J. Vera, M.F. Ortuño, and M.C. Ruiz-Sánchez. 2015. Stem water potential estimation of dripirrigated early-maturing peach trees under Mediterranean conditions. Comput. Electron. Agr. 114:7-13, doi: 10.1016/j.compag.2015.03.004.

Baggiolini, M. 1980. Stades repères du cerisierStades repères du prunier. Stades repères de l'abricotier. Stades repères du pêcher. ACTA. Guide Pratique de Défense des Cultures Paris, France.

Baldi, E., M. Toselli, D.M. Eissenstat, and B. Marangoni. 2010. Organic fertilization leads to increased peach root production and lifespan. Tree Physiol. 30:1373-1382, doi: 10.1093/treephys/tpq078.

Baligar, V.C., N.K. Fageria, and Z.L. He. 2001. Nutrient use efficiency in plants. Commun. Soil Sci. Plant Anal. 32(7\&8):921-950, doi: 10.1081/CSS-100104098.

Başar, H. 2006. Elemental composition of various peach cultivars. Scientia Hort. 107:259-263, doi: 10.1016/j.scienta.2005.08.004.

Berman, M.E. and T.M. DeJong. 1996. Water stress and crop load effects on fruit fresh and dry weights in peach (Prunus persica). Tree Physiol. 16:859-864, doi: 10.1093/treephys/ 16.10.859.

Boland, A.M., P.H. Jerie, P.D. Mitchell, I. Goodwin, and D.J. Connor. 2000. Long-term effects of restricted root volume and regulated deficit irrigation on peach: I. Growth and mineral nutrition. J. Amer. Soc. Hort. Sci. 125(1):135-142, doi: 10.21273/JASHS.125.1.135

California Department of Water Resources. 2015. Drought in California. Sacramento, CA.

Casamali, B. 2019. Irrigation and fertilization practices for young peach trees in the southeastern United States. Univ. of Ga., Athens. PhD Diss.

Connors, C.H. 1919. Growth of fruits of peach. N.J. Agr. Expt. Sta. Annu. Rpt. 40:82-88.

Crisosto, C.H., R.S. Johnson, T. DeJong, and K.R. Day. 1997. Orchard factors affecting posthar- vest stone fruit quality. HortScience 32:820 823, doi: 10.21273/HORTSCI.32.5.820.

Dichio, B., C. Xiloyannis, A. Sofo, and G. Montanaro. 2007. Effects of post-harvest regulated deficit irrigation on carbohydrate and nitrogen partitioning, yield quality and vegetative growth of peach trees. Plant Soil 290:127137, doi: 10.1007/s11104-006-9144-x.

Ferree, M.E. and G.W. Krewer. 1996. Peaches and nectarines. Univ. Georgia Coop. Ext. Serv., Athens, GA.

Ferreira, L.V., L. Picolotto, I. dos S. Pereira, J.D. Schmitz, and L.E.C. Antunes. 2018. Nitrogen fertilization in consecutive cycles and its impact on high-density peach crops. Pesquisa Agropecuaria Brasileira 53:172-181, doi: 10.1590/s0100-204×2018000200005.

Gammon, Jr., N. and J.S. Shoemaker. 1963. Effect of fertilizers on mineral levels in the leaves of Flordawon peach. Florida State Hort. Soc. 1746:380-384.

Girona, J., M. Gelly, M. Mata, A. Arbonès, J. Rufat, and J. Marsal. 2005. Peach tree response to single and combined deficit irrigation regimes in deep soils. Agr. Water Mgt. 72:97108, doi: 10.1016/j.agwat.2004.09.011.

Goldhamer, D.A., E. Fereres, M. Mata, J. Girona, and M. Cohen. 1999. Sensitivity of continuous and discrete plant and soil water status monitoring in peach trees subjected to deficit irrigation. J. Amer. Soc. Hort. Sci. 124:437-444, doi: 10.21273/JASHS.124.4.437.

Goldhamer, D.A., M. Salinas, C. Crisosto, K.R. Day, M. Soler, and A. Moriana. 2002. Effects of regulated deficit irrigation and partial root zone drying on late harvest peach tree performance. Acta Hort. 592:343-350, doi: 10.17660/ActaHortic.2002.592.48.

Haider, M.S., M.M. Kurjogi, M. Khalil-ur-Rehman, T. Pervez, J. Songtao, M. Fiaz, S. Jogaiah, C. Wang, and J. Fang. 2018. Drought stress revealed physiological, biochemical and gene-expressional variations in 'Yoshihime' peach (Prunus Persica L.) cultivar. J. Plant Interact. 13:83-90, doi: 10.1080/17429145.2018.1432772.

Heckman, J. 2001. Leaf analysis for fruit trees. New Jersey Agr. Expt. Sta. FS627, New Brunswick, NJ.

Hoerling, M., J. Eischeid, J. Perlwitz, X. Quan, T. Zhang, and P. Pegion. 2012. On the increased frequency of Mediterranean drought. J. Clim. 25:2146-2161, doi: 10.1175/JCLI-D-11-00296.1.

Horton, D., P. Brannen, B. Bellinger, D. Lockwood, and D. Ritchie. 2015. 2015 Southeastern peach, nectarine, and plum pest management and culture guide. Univ. Georgia Coop. Ext. Bul. 1171. Athens, GA.

Iacona, C., M. Cirilli, A. Zega, E. Frioni, C Silvestri, and R. Muleo. 2013. A somaclonal myrobalan rootstock increases waterlogging tolerance to peach cultivar in controlled conditions. Scientia Hort. 156:1-8, doi: 10.1016/ j.scienta.2013.03.014

Johnson, R.S., D.F. Handley, and T.M. DeJong. 1992. Long-term response of early maturing peach trees to postharvest water deficits. J. Amer. Soc. Hort. Sci. 117(6):881-886, doi: 10.21273/JASHS.117.6.881.

Jordan, M.-O., G. Vercambre, L. Gomez, and L. Pages. 2014. The early spring $\mathrm{N}$ uptake of young peach trees (Prunus persica) is affected by past and current fertilizations and levels of $C$ and $\mathrm{N}$ stores. Tree Physiol. 34:61-72, doi: 10.1093/treephys/tpt109.

Layne, D.R., D.B. Cox, and E.J. Hitzler. 2002. Peach systems trial: The influence of training system, tree density, rootstock, irrigation and fertility on growth and yield of young trees in 
South Carolina. Acta Hort. 592:367-375, doi: 10.17660/ActaHortic.2002.592.51.

Layne, R.E.C., C.S. Tan, and D.M. Hunter. 1996. Irrigation and fertilizer application methods affect performance of high-density peach orchards. HortScience 31:370-375, doi: 10.21273/ HORTSCI.31.3.370.

Lobit, P., P. Soing, M. Génard, and R. Habib. 2001. Effects of timing of nitrogen fertilization on shoot development in peach (Prunus persica) trees. Tree Physiol. 20:35-42, doi: 10.1093/ treephys/21.1.35.

Lopez, G., M. Hossein Behboudian, G. Echeverria, J. Girona, and J. Marsal. 2011. Instrumental and sensory evaluation of fruit quality for 'Ryan's sun' peach grown under deficit irrigation. HortTechnology 21:712-719, doi: 10.21273/HORTTECH.21.6.712.

Mahhou, A., T.M. DeJong, T. Cao, and K.S. Shackel. 2005. Water stress and crop load effects on vegetative and fruit growth of 'Elegant Lady' peach [Prunus persica $(\mathrm{L}$.) Batch] trees. Fruits 60:55-68, doi: 10.1051/fruits:2005013.

Marsal, J., J. Casadesus, G. Lopez, M. Mata, J. Bellvert, and J. Girona. 2016. Sustainability of regulated deficit irrigation in a mid-maturing peach cultivar. Irr. Sci. 34:201-208, doi: 10.1007/s00271-016-0498-4.

Mercier, V., C. Bussi, F. Lescourret, and M. Génard. 2009. Effects of different irrigation regimes applied during the final stage of rapid growth on an early maturing peach cultivar. Irr. Sci. 27:297-306, doi: 10.1007/s00271-0090146-3.

Mirás-Avalos, J.M., R. Alcobendas, J.J. Alarcón, P. Valsesia, M. Génard, and E. Nicolás. 2013. Assessment of the water stress effects on peach fruit quality and size using a fruit tree model, QualiTree. Agr. Water Mgt. 128:1-12, doi: 10.1016/j.agwat.2013.06.008.

Niederholzer, F.J.A., T.M. DeJong, J.-L. Saenz, T.T. Muraoka, and S.A. Weinbaum. 2001. Effectiveness of fall versus spring soil fertilization of field-grown peach trees. J. Amer. Soc. Hort. Sci. 125:644-648, doi: 10.21273/ JASHS.126.5.644.

Nyczepir, A.P. and T.G. Beckman. 2000. Host status of guardian peach rootstock to Meloidogyne sp. and M. javanica. HortScience 35:772, doi: 10.21273/HORTSCI.35.4.772.
Okie, W.R. and D.R. Layne. 2008. 'Scarletprince' and 'Julyprince' peaches. HortScience 43:16031605, doi: 10.21273/HORTSCI.43.5.1603.

Okie, W.T. 2016. The Georgia peach: Culture, agriculture, and environment in the American south. Cambridge University Press, New York, NY.

Olmstead, M., L. Zotarelli, J. Brecht, and M. Ross. 2015. Impact of nitrogen on vegetative growth of mature peach trees in a subtropical climate. Acta Hort. 1084:459-464, doi: 10.17660/ActaHortic.2015.1084.63.

Pascual, M., J.M. Villar, and J. Rufat. 2016. Water use efficiency in peach trees over a four-years experiment on the effects of irrigation and nitrogen application. Agr. Water Mgt. 164:253-266, doi: 10.1016/j.agwat.2015.10.021.

Perea, R.G., A. Daccache, J.A. Rodríguez Díaz, E. Camacho Poyato, and J.W. Knox. 2018. Modelling impacts of precision irrigation on crop yield and in-field water management. Precis. Agr. 19:497-512, doi: 10.1007/s11119-017-9535-4.

Proebsting, Jr., E.L. and J.E. Middleton. 1980. The behavior of peach and pear trees under extreme drought stress. J. Amer. Soc. Hort. Sci. 105:380-385.

Ray, D.K., J.S. Gerber, G.K. Macdonald, and P.C. West. 2015. Climate variation explains a third of global crop yield variability. Nat. Commun. 6(5989), doi: 10.1038/ncomms6989.

Rahmati, M., G.H. Davarynejad, M. Génard, M. Bannayan, M. Azizi, and G. Vercambre. 2015. Peach water relations, gas exchange, growth and shoot mortality under water deficit in semi-arid weather conditions. PLoS One 10:e120246, doi: 10.1371/journal.pone.0120246.

Reighard, G.L., W.C. Newall, Jr., T.G. Beckman, W.R. Okie, E.I. Zehr, and A.P. Nyczepir. 1997. Field performance of Prunus rootstock cultivars and selection on replants soil in South Carolina. Acta Hort. 451:243-249, doi: 10.17660/ActaHortic.1997.451.26.

Rosenzweig, C., J. Elliott, D. Deryng, A.C. Ruane, C. Müller, A. Arneth, K.J. Boote, C. Folberth, M. Glotter, N. Khabarov, K. Neumann, F. Piontek, T.A.M. Pugh, E. Schmid, E. Stehfest, H. Yang, and J.W. Jones. 2014. Assessing agricultural risks of climate change in the 21 st century in a global gridded crop model intercomparison. Proc. Natl. Acad. Sci. USA 111:3268-3273, doi: 10.1073/pnas. 1222463110 .
Smith, C.B. and G.A. Taylor. 1952. Tentative optimum leaf concentration of several elements for Elberta peach and Stayman apple in Pennsylvania orchards. Proc. Amer. Soc. Hort. Sci. 60:33-41.

Tagliavini, M., D. Scudellazi, B. Marangoni, and M. Toselli. 1996. Nitrogen fertilization management in orchards to reconcile productivity and environmental aspects, p. 161-170. In: C. Rodriguez-Barrueco (ed.). Fertilizer and environment: Developments in plant and soil sciences. Springer, Dordrecht, The Netherlands.

Taylor, K.C. 2012. Peach orchard establishment and young tree care. Univ. Georgia Coop. Ext. Serv., Athens, GA.

Tormann, H. 1986. Canopy temperature as a plant water stress indicator for nectarines. S. Afr. J. Plant Soil 3:110-114, doi: 10.1080/02571862. 1986.10634203

U.S. Department of Agriculture, Forest Service. 2018. Drought impacts in the Southern region. U.S. Department of Agriculture Forest Service, Washington, D.C.

U.S. Department of Agriculture, National Agricultural Statistics Service. 2007. 2007 Census of agriculture. State Profile. U.S. Department of Agriculture, Washington, D.C.

U.S. Department of Agriculture, National Agricultural Statistics Service. 2017. Noncitrus Fruits and Nuts-2016 Summary. U.S. Department of Agriculture, Washington, D.C.

Vashisth, T., M.A. Olmstead, J. Olmstead, and T.A. Colquhoun. 2017. Effects of nitrogen fertilization on subtropical peach fruit quality: Organic acids, phytochemical content, and total antioxidant capacity. J. Amer. Soc. Hort. Sci. 142:393-404, doi: 10.21273/JASHS04011-16.

Washington State University. n.d. Peaches: Critical temperatures for blossom buds. 6 Apr. 2019. $<$ https://s3.wp.wsu.edu/uploads/sites/2086/ 2014/05/budchph.jpg>.

Williamson, J.G. and D.C. Coston. 1990. Planting method and irrigation rate influence vegetative and reproductive growth of peach planted at high density. J. Amer. Soc. Hort. Sci. 115:207212, doi: 10.21273/JASHS.115.2.207.

Zhang, X., E.A. Davidson, D.L. Mauzerall, T.D. Searchinger, P. Dumas, and Y. Shen. 2015. Managing nitrogen for sustainable development. Nature 528:51-59, doi: 10.1038/nature15743. 